\title{
Possible Retard in the Language Development to the Children Born through IVF (In Vitro Fertilisation)
}

\author{
RAMONA NEDELCUTA ${ }^{1 *}$, VLAD DUMITRU BALEANU2*\#, COSMIN CIORA ${ }^{3}$, GIGI CALIN ${ }^{1}$, MIHAIL-RELU STANESCU4, \\ DRAGOS VIRGIL DAVITOIU55, TIBERIU STEFANITA TENEA-COJAN6, BOGDAN SOCEA ${ }^{5}$, DANIEL-IULIAN VOICULESCU7\#, \\ DRAGOS OVIDIU ALEXANDRU ${ }^{8}$, RADU STANESCU4\# \\ 'University of Medicine and Pharmacy of Craiova, Department of Pediatrics, 2 Petru Rares Str., 200349, Craiova, Romania \\ 2University of Medicine and Pharmacy of Craiova, Surgery Department, Clinical Emergency Hospital Sf. Pantelimon Bucharest, \\ 340-342 Pantelimon Road, 021659, Bucharest, Romania \\ ${ }^{3}$ Carol Davila University of Medicine and Pharmacy, Dionisie Lupu 37, 020021, Bucharest, Romania \\ ${ }^{4}$ University of Medicine and Pharmacy of Craiova, Department of Morphological Sciences, 2 Petru Rares Str., 200349, Craiova, \\ Romania \\ ${ }^{5}$ University of Medicine and Pharmacy of Bucharest, Surgery Department, Clinical Emergency Hospital Sf. Pantelimon Bucharest, \\ 340-342 Pantelimon Road, 021659, Bucharest, Romania \\ ${ }^{6}$ University of Medicine and Pharmacy of Craiova, Department of Surgery, CFR Hospital of Craiova, Stirbei-Voda Str., 200374, \\ Craiova, Romania \\ 7University of Medicine and Pharmacy Carol Davila Bucharest, Department of Surgery Universitary Emergency Hospital Bucharest, \\ 169 Splaiul Indepentei, 050098, Bucharest, Romania \\ ${ }^{8}$ University of Medicine and Pharmacy of Craiova, Department of Medical Informatics and Biostatistics, 661 Mai Blvd, 200638, \\ Craiova, Romania
}

Research in recentyears on a possible and evident pathology, appeared in children's case from pregnancies obtained through in vitro fertilization (IVF), did not show significant differences than the children born from pregnancies obtained naturally. Having a good start in life, the consignments studied were feed exclusively in a natural way in the first 6 months, knowing the complex role of breast milk, including nerve growth. The delay in language development has shown significant differences between the IVF consignment and the control group and the pathology exam a possible involvement in cerebral embryogenesis, especially the Broca's area, of some disturbing factors, with a maximum of action before the $23^{d}$ week.

Keywords: Broca's area, language, IVF, natural feeding

Infertility affects $1 / 5$ couples at global classification level and the number of infertile people who appeal to assisted fertilization techniques raises annually with $8-9 \%$.

Atpresent, atEuropean level, there are 25 million people who present infertility problems.

A study realized in Romania in April-May 2018 to the Human Reproduction Association demand (realized by Quantix Marketing Consulting), on a sample of 4680 people, has objectified an infertility percent of $16.8 \%$, over the percent of the European statistics.

IVF is a option more and more used once with increasing demands for infertile couples. Success rate is maintained to $30-40 \%$ in function of multiple factors (the couple's age, hormone level, illness, lifestyle, and so on). It suppose a hormonal stimulation phase by follicular development process, ovaries stimulating to get a big number of follicles, procurement through fertilization with sperm count, embryonic transfer. Then, it is realized the embryonic hatching (sometimes assisted, laser) and implantation luteal phase hormonally sustained. The pregnancy is followed even earlyier since 2 weeks, through HCG measurement.

\section{Experimental part}

\section{Material and method}

A consignment of 100 infants born in the same period, prospective study during 5 years - 50 cases after IVF and 50 cases pregnancies obtained naturally.

In all cases, children were born through caesarean and were feed exclusively in a natural way for 6 months.
The were followed more parameters:

-the age of the parents

-birth rank, multiple pregnancies

-mum's associated pathology

-hormonal treatment during pregnancy

-Apgar scoring

-weight at birth

-perinatal pathology

-evolution on growth percentiles

-natural food

-diversification

-associated pathology

-cognitive neuropsychiatric development

-integration in community

Children were evaluated monthly in the first 12 months, then quarterly in the following years, for 36 months.

\section{Results and discussions}

The genitor's age was between 35-47 at children got from IVF and 19-42 at those got naturally. The mother's general pathology did nothave any noticeable particularities in the IVF group compared to the blank.

Mother's gynecological pathology has presented a high share at the IVF group.

$35 \%$ of mothers have presented metroanexitis, polycystic ovary or endometritis in upward than $9 \%$ in the control group (fig.1).

Multiple pregnancies occurred significantly more frequently in the FIV group ( 10 children) of $20 \%$ ( 6 triplets) 


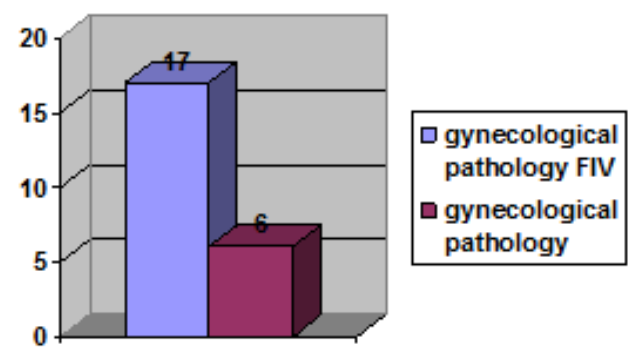

Fig. 1

compared to $8 \%$ in the control group. ( 2 pregnancies with twins) (fig.2).

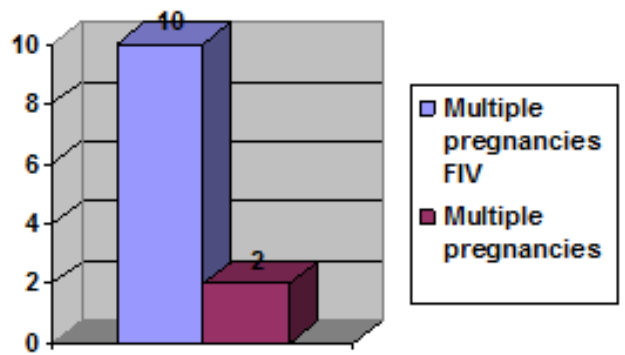

Fig. 2

Apgar score in IVF group was 9 at $60 \%$ (30 cases), 8 at $28 \%$ ( 14 cases), 7 at $8 \%$ ( 4 cases) and 5 at $4 \%$ ( 2 cases). In the case of the control group the score 9 was at 38 cases $(76 \%)$, score 8 for 8 cases (16\%), respectively 7 in 4 cases (8\%) (fig.3,4).
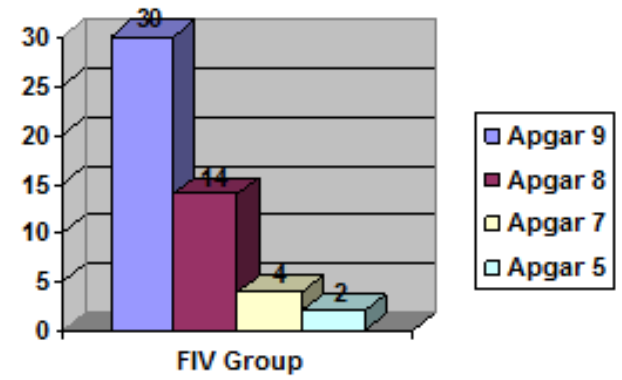

Fig. 3

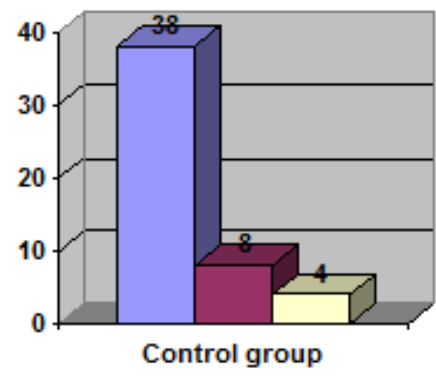

Fig. 4

The weight at birth was between 2750-3900 and at the control and at IVF, excepting the triplets or twins series with w eight of 900-1100 to an inferior limit at IVF and 15001850 to those with pregnancy got naturally.

Perinatal needed prolonged hospitalization to the premature infants with low birth weight (an average of 37 days) and 2 with natural births that presented a difficult adaptation.

Physiological jaundice was present to all patients, the most prolonged being at 14\% from IVF (7 cases) and at $10 \%$ from natural births ( 5 cases) (fig.5).

All of them were feed exclusively in a natural way for the first 6 months and the diversification has been framed in normal parameters. The baby's pathology has presented

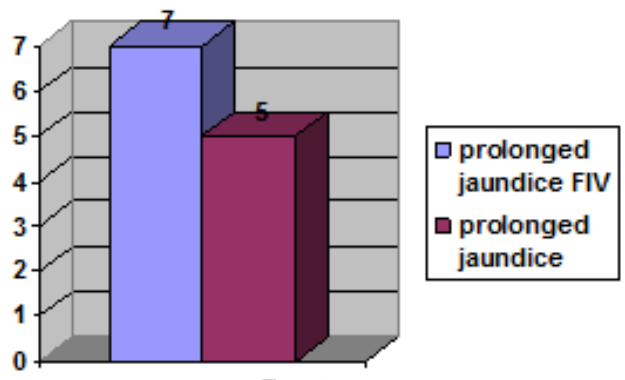

Fig. 5

small variations - 7-8 episodes of acute superior airways infection / year / child as an average to IVF group and 5-6 to control group.

The share was slightly increased in multiple pregnancies - 8-9 episodes per year.

This may be a parameter not so real, the attention accorded by children's parents considered precious IVF being a little bigger than the attention that given to control group where some episodes could be passed as unnoticed.

Notable differences have appeared in neuropsychic and cognitive development and were visible after 4 months.

In the control group, 96\% (48 cases) were tarnishing and were sitting down at 5 months and $84 \%$ from IVF (42 cases). At 6 months, the palmo-cubital gripping with the transfer of objects from one hand to another is realized at 95\% from control group and $86 \%$ from IVF (fig.6).

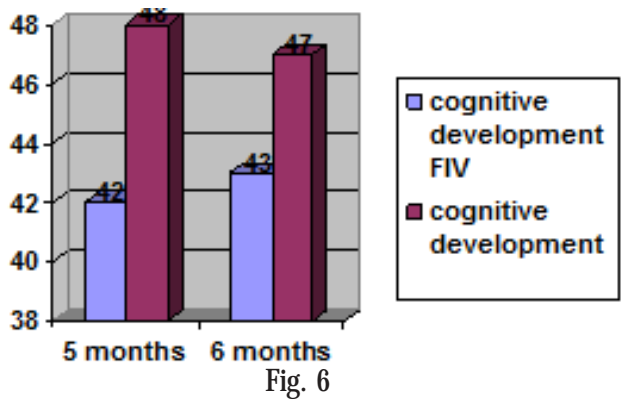

At 7 months, lala language was presented at $88 \%$ (44 children) from control group and $68 \%$ (34 children) from IVF group, slightly modified until 9 months ( $92 \%$ control and $72 \%$ IVF) (fig.7).

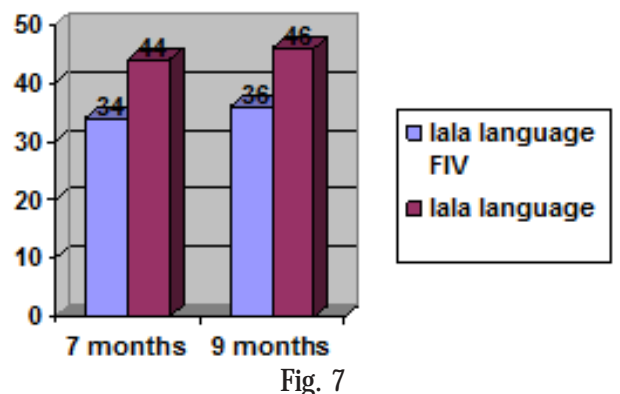

Walking has been installed between 10-14 months to the majority of children ( $94 \%$ control and $92 \%$ FIV) (fig.8).

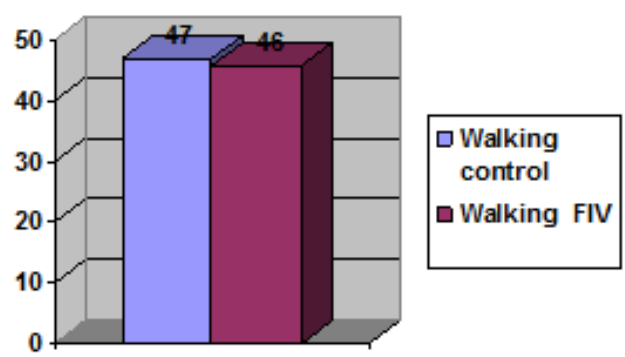

Fig. 8 
Significant differences occurred to the language development during 12-30 months. 20 cases from IVF group (40\%) presented a delay in language development at 30 months.

In control group, $12 \%$ presented delays of language delays until almost 30 months.

At 4 years old $24 \%$ from IVF had a delay ( 12 cases, among these ones 1 case being diagnosed with autism). At witness group, the proportion was of 2 cases (4\%), the difference being significant (fig.9).

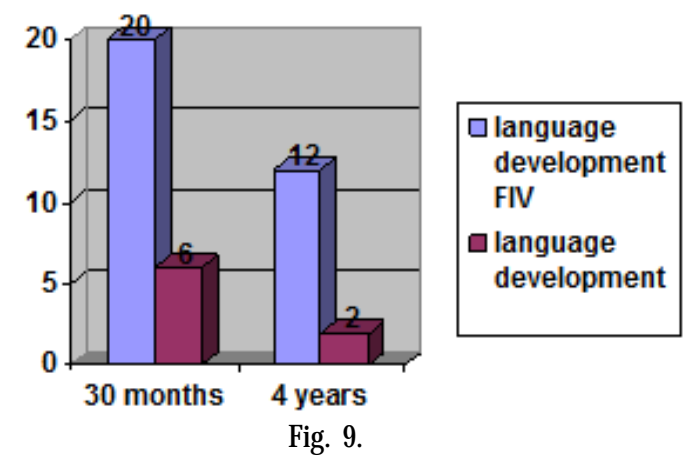

A sampling was made from the fragment from the left superior left sulcus and from the hemispheres to fetuses from week 16-23.

At the 18-week-old fetus brain: a rich populated paraventricular reservoir with neuroblasts (fig. 10), from which start thin rays of radial migration (fig. 11) start to the cortex already undifferentiated stratigraphic.

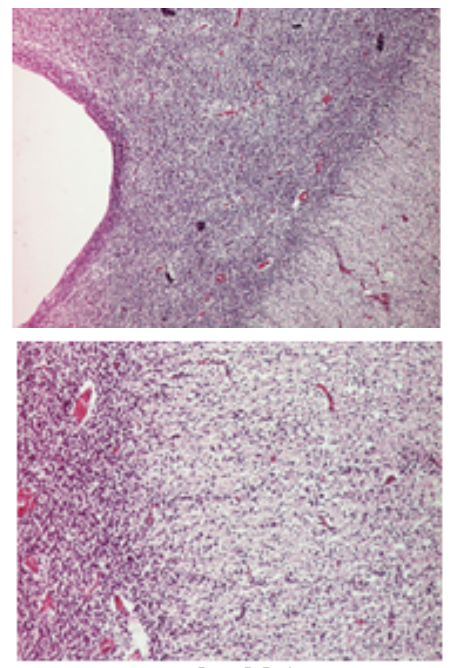

Fig.10.A lacunar zone

Fig.11. Thin rays of radial migration

At 23-week-old fetus we noticed an obvious sketch of the lateral sulcus, which allowed a more accurate localization of the area in which will be formed the Broca's area. The paraventricular zone was well highlighted, but cellular depletion phenomena distributed as diffuse islets located inside it, as well as with a lacunar zone relatively large that separates the paraventricular zone from the marginal zone, paradoxically, richer cellular (fig. 12). Even if this lacunar zone was crossed by neuroblastic bands glial guided which were starting under bundles with perivascular origin (fig. 13).

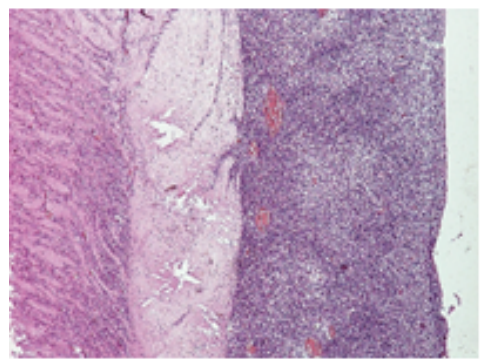

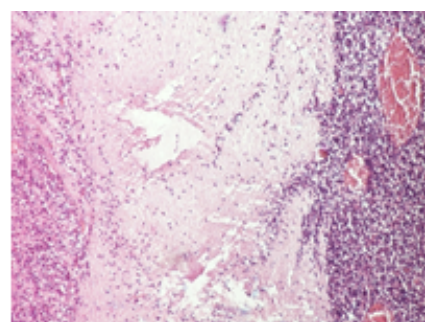

Fig. 13. Neuroblasts layer

-The anatomo-pathological visualization according to the week of gestation of the cerebral maturaty that places possible embryological development vices after the 16th week.

-Neural cortical migration of the lacunar zones crossed by neuroblastic bands situated perivascular, is appeared in the week 23 and localizes precise enough the first outline of lateral ditch and also the future Broca's area.

The constitutive hormonal medication administered in the first part as IVF therapy could cause interference, a slight edema of the neural structure, neoformation which influences the future projection or association areas that intervenes in language.

Maternal milk is a vivid nourishment with complex composition that contains among many other constituents, a nervous growth factor secreting IgA (with a role in immune defense). The study lot was uniform under the aspect of breastfeeding exclusively for the first 6 months.

Although most children conceived by intracytoplasmic sperm injection (ICSI) are healthy and develop normally, there is an increased risk of mild delays in development at 1 year when compared with children conceived by routine IVF or conceived naturally [2].

Place and Englert found a lower mean IQ in IVF and ICSI children compared with spontaneously conceived (SC) children aged 0-5 years, but this difference disappeared after adjusting for parental education [3].

Ponjaert-Kristoffersen et al. [4] showed that, although there were no differences in the IQ of IVF/ICSI and control children at age 5 years, older maternal age at birth was significantly linked to lower full-scale IQ and verbal IQ as well as lower abilities on a subtest of the performance scale (object assembly) in IVF/ICSI children. Higher maternal educational level was linked to better abilities on the object assembly scale, whereas lower maternal educational level was linked to lower scores on spatial visualization analysis [4].

A large population-based registry study assessing the development of neurological sequelae in 5,680 children born after IVF, aged 18 months to 14 years, and 11,360 matched controls noted that IVF children have an almost fourfold increased risk of cerebral palsy and suspected developmental delay as compared with matched controls [5].

The use of gonadotrophins for ovarian stimulation is the most important cause of multiple pregnancies in assisted reproductive technology (ART) patients in the United States, with one-third of multiple pregnancies being caused by non-IVF ovarian stimulation [6].

Multiple pregnancies are associated with increased risk of miscarriage, growth retardation and preterm delivery [7-13].

However, even singletons are at higher risk of low birthweight, premature birth and perinatal mortality and morbidity in the subfertile population using ART [14-21].

Since low birthweight in humans may be an important risk factor for the development of neurological disorders and adult-onset diseases such as coronary heart disease, stroke, hypertension, type II diabetes and osteoporosis, 
ovarian stimulation could even have adverse effects in adult life [22-33].

\section{Conclusions}

Assisted pregnancies represent a reality more and more frequent of the last years, with a growing trend in the civilized countries.

The socio-economic level of families with IVF patients was over the average to more than $90 \%$ compared to $67 \%$ in those appeared in a natural way.

The increasingly successful process brings successful and joyful percentages. The couples' age is usually over the average; a pregnancy appeared after many attempts or assisted insemination. The educational and socioeconomic level of families using IVF is over the average, the procedures being expensive and laborious.

The hormonal treatment and the reject embryo prevention treatment are parts of the IVF protocol.

Children born after IVF procedure did not present notable differences in the somatic development or diseases acquired, but they present significant differences in the development of the second signal system - the language.

Early development of the neuronal system in embryogenesis can present interferences with hormonal medication administered to mother during the first weeks. Some other malformations could also be explained [34].

Possible explanations of correlations between IVF and language development:

-Hormones administered before IVF

-Manipulation of genetic material (possible inductions/ deletions/translocations) of ICSI

-Cultures - transfer of affected blastocyst

-Uterine microbial of the infertile mother who underwent numerous previous investigations / treatments

-Epigenetics

-Methylation of some DNA groups/fractions

-The maternal anxiety during the first trimester which rises the oxidative stress and it is coupled with increased retardation of fetus NS differentiation and formation.

\section{References}

1. GOLDBERG, J.M., FALCONE, T., ATTARAN, M., Cleve Clin J Med, 74, no. 5, 2007, p. 329

2. BOWEN, J.R., GIBSON, F.L., LESLIE, G.I., SAUNDERS, D.M., Lancet, 351, 1998, p. 1529

3. PLACE, I., ENGLERT, Y., Fertil Steril, 80, 2003, p. 1388

4. PONJ AERT-KRISTOFFERSEN, I., BONDUELLE, M., BARNES, J., NEKKEBROECK, J., LOFT, A., WENNERHOLM, U., et al., Paediatrics, 115e, 2005, p. 283

5. STROMBERG, B., DAHLQUIST, G., ERICSON, A., FINNSTROM, O., KOSTER, M., STJERNQVIST, K., Lancet, 359, 2002, p. 461

6. OMBELET, W., MARTENS, G., DE SUTTER, P., GERRIS, J., BOSMANS, E., RUYSSINCK, G., DEFOORT, P., MOLENBERGHS, G., GYSELAERS, W., Human Reproduction, 21, 2006, p. 1025

7. FAUSER, B.C., DEVROEY, P., MACKLON, N.S., Lancet, 365, 2005, pp. 1807-1816.

8. CALIN, F.D., DIMITRIU, M.C.T., PACU, I., CIOBANU, A.M., BANACU, M., POPESCU, I., TARCOMNICU, I.M., CEAUSU, Z., VLADESCU, T., SOCEA, B., FURAU, C., FURAU, G., IONESCU, C.A., Arch Balk Med Union, 51, no. 2, 2016, p. 261

9. TARCOMNICU, I.M., DIMITRIU, M.C.T., CALIN, R.A., GHEORGHIU, D., PACU, I., CALIN, F.D., BANACU, M., POPESCU, I., HANGANU, I., VLADESCU, T., SOCEA, B., FURAU, C.G., FURAU, G., BACALBASA, N., JITIANU, C.R., POPA, F., IONESCU, C.A., Arch Balk Med Union, 51, no. 2, 2016, p. 273

10. CALIN, F.D., CIOBANU, A.M., DIMITRIU, M.C.T., PACU, I., BANACU, M., POPESCU, I., TARCOMNICU, I.M., CEAUSU, Z., SOCEA, B., PAUNICAPANEA, G., FURAU, C.G., FURAU, G.O., BACALBASA, N., GHEORGHIU, D., IONESCU, C.A., Arch Balk Med Union, 51, no. 3, 2016, p. 445 11. POPESCU, I., BUTUC, V., BUTUC, S., PACU, I., IONESCU, C.A., BANACU, M., TARCOMNICU, I., CALIN, D., SOCEA, B., COROLEUCA,
C.B., FURAU, C.G., FURAU, G.O., BACALBASA, N., BANU, C., DIMITRIU, M.C.T., Arch Balk Med Union, 51, no. 3, 2016, p. 451

12. BODEAN, O., BRATU, O., BOHILTEA, R., MUNTEANU, O., MARCU, D., SPINU, D.A., VACAROIU, I.A., SOCEA, B., DIACONU, C.C., FOMETESCU GRADINARU, D., CIRSTOIU, M., Rev. Chim. (Bucharest), 69, no. 6, 2018, p. 1411

13. DIMITRIU, M., SOCEA, B., PLES, L., GHEORGHIU, D.C., GHEORGHIU, N., NEACSU, A., CIRSTOVEANU, C.G., BACALBASA, N., FURAU, C.G., FURAU, G.O., BANACU, M., IONESCU, C.A., Rev. Chim. (Bucharest), 70, no. 3, 2019, p. 1058

14. SCHIEVE, L.A., MEIKLE, S.F, FERRE, C., PETERSON, H.B., JENG, G., WILCOX, L.S., New England J ournal of Medicine, 346, 2002, p. 731 15. HELMERHORST, F.M., PERQUIN, D.A., DONKER, D., KEIRSE, M.J ., BMJ, 328, 2004, p. 261

16. JACKSON, R.A., GIBSON, K.A., WU, Y.W., CROUGHAN, M.S., Obstetrics and Gynecology, 103, 2004, p. 551

17. KAPITEIJN, K., DE BRUIJN, C.S., DE BOER, E., DE CRAEN, A.J., BURGER, C.W., VAN LEEUWEN, F.E., HELMERHORST, F.M., Human Reproduction, 21, 2006, p. 3228

18. RADU, L., CARSOTE, M., PREDESCU, A.M., TENEA COJAN, T.S., SOCEA, B., BALEANU, V.D., POPESCU, M., IONOVICI, N., ALBULESCU,

D.M., Rev. Chim. (Bucharest), 69, no. 12, 2018, p. 3483

19. VLADU, I.M., RADU, L., GIRGAVU, S.R., BALEANU, V., CLENCIU, D., ENE, C.G., SOCEA, B., MAZEN, E., CRISTEA, O.M., MOTA, M., TENEA COJAN, T.S., Rev. Chim. (Bucharest), 69, no.11, 2018, p. 4229

20. GHEORMAN, V., CHIRITA, A.L., DUMITRESCU, E.M., ROGOVEANU, I., ISTRATOAIE, O., GHEORMAN, V., PANA, R.C., Romanian J ournal of Morphology and Embryology, 57, no. 1, 2016, p. 45

21. NEDELCUTA, R.M., CALIN, G., CIORA, C.A., BALEANU, V., DAVITOIU, D., Research and Science Today, 17, no. 1, 2019, p. 239 22. FLEMING, T.P., KWONG, W.Y., PORTER, R., URSELL, E., FESENKO, I., WILKINS, A., MILLER, D.J., WATKINS, A.J ., ECKERT, J.J ., Biology of Reproduction, 71, 2004, p. 1046

23. BRATU, O.G., MARCU, R.D., SOCEA, B., NEAGU, T.P., DIACONU, C.C., SCARNECIU, I., TURCU, F.L., RADAVOI, G.D., BRATILA, E., BERCEANU, C., SPINU, A.D., Rev. Chim. (Bucharest), 69, no. 7, 2018, p. 1813

24. DIACONU, C.C., MANEA, M., IANCU, M.A., STANESCU, A.M.A., SOCEA, B., SPINU, D.A., MARCU, D., BRATU, O.G., Rev. Chim. (Bucharest), 69, no. 5, 2018, p. 1071

25. DIACONU, C.C., DRAGOI, C.M., BRATU, O.G., NEAGU, T.P., PANTEA STOIAN, A., COBELSCHI, P.C., NICOLAE, A.C., IANCU, M.A., HAINAROSIE, R., STANESCU, A.M.A., SOCEA, B., Farmacia, 66, no. 3, 2018, p. 408

26. DIACONU, C.C., STANESCU, A.M.A., PANTEA STOIAN, A., TINCU, R.C., COBILINSCHI, C., DRAGOMIRESCU, R.I.F., SOCEA, B., SPINU, D.A., MARCU, D., SOCEA, L.I., BRATU, O.G., Rev. Chim. (Bucharest), 69, no. 6, 2018, p. 1367

27. TICA, O.A., TICA, O., ANTAL, L., HATOS, A., POPESCU, M.I., PANTEA STOIAN, A., BRATU, O.G., GAMAN, M.A., PITURU, S.M., DIACONU, C.C., Farmacia, 66, no. 6, 2018, p. 972

28. MANEA, M., MARCU, D., PANTEA STOIAN, A., GAMAN, M.A., GAMAN, A.M., SOCEA, B., NEAGU, T.P., STANESCU, A.M.A., BRATU, O.G., DIACONU, C.C., Rev. Chim. (Bucharest), 69, no. 11, 2018, p. 4180

29. BODEAN, O., BRATU, O., BOHILTEA, R., MUNTEANU, O., MARCU, D., SPINU, D. A., VACAROIU, I. A., SOCEA, B., DIACONU, C. C., FOMETESCU GRADINARU, D., CIRSTOIU, M., Rev. Chim. (Bucharest), 69, no. 6, 2018, p. 1411

30. MARCU, R.D., SPINU, A.D., SOCEA, B., BODEAN, M.O., DIACONU, C.C., VASILESCU, F., NEAGU, T.P., BRATU, O.G., Rev. Chim. (Bucharest), 69 , no. 4, 2018, p. 823

31. IONESCU, C.A., DIMITRIU, M., POENARU, E., BANACU, M., FURAU G.O., NAVOLAN, D., PLES, L., J ournal of Evaluation in Clinical Practice, 25, no. 1, 2019, p. 111

32. NEACSU, A., CALIN, A., BRAILA, A.D., NAVOLAN, D., DIMITRIU, M., STANICA, C.D., IOAN, R., IONESCU, C., Rev. Chim. (Bucharest), 69, no. 7, 2018, p. 1796

33. DIMITRIU, M., IONESCU, C.A., MATEI, A., VIEZUINA, R., ROSU, G., ILINCA, C., BANACU, M., PLES, L., J ournal of Evaluation in Clinical Practice, 25, no. 1, p. 117

34. SOCEA, B., CONSTANTIN, V., CARAP, A., MOCULESCU, C., PADEANU, N., POPA, F., Chirurgia, 107, no. 5, 2012, p. 659

Manuscript received: 7.10 .2018 